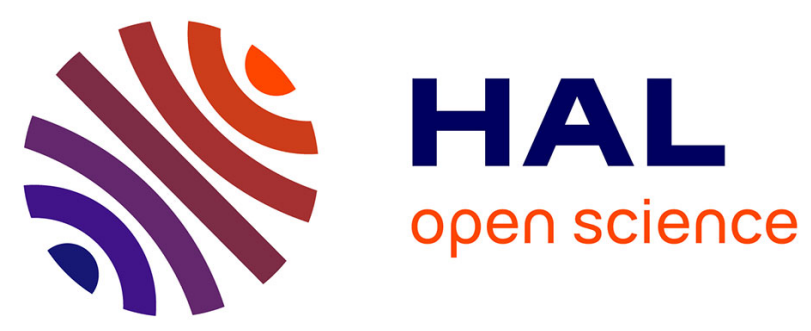

\title{
Ammonite stratigraphy and the belemnite genus Hibolithes in the higher Serdj Formation (Aptian-Albian boundary interval) in north central Tunisia
}

Jens Lehmann, Ekbert Seibertz, Christian Spaeth, Luc Bulot

\section{- To cite this version:}

Jens Lehmann, Ekbert Seibertz, Christian Spaeth, Luc Bulot. Ammonite stratigraphy and the belemnite genus Hibolithes in the higher Serdj Formation (Aptian-Albian boundary interval) in north central Tunisia. Zeitschrift der Deutschen Gesellschaft für Geowissenschaften ZDGG, 2020, 171 (2), pp.135148. 10.1127/zdgg/2020/0210 . hal-03016315

\section{HAL Id: hal-03016315 https://hal.science/hal-03016315}

Submitted on 20 Nov 2020

HAL is a multi-disciplinary open access archive for the deposit and dissemination of scientific research documents, whether they are published or not. The documents may come from teaching and research institutions in France or abroad, or from public or private research centers.
L'archive ouverte pluridisciplinaire HAL, est destinée au dépôt et à la diffusion de documents scientifiques de niveau recherche, publiés ou non, émanant des établissements d'enseignement et de recherche français ou étrangers, des laboratoires publics ou privés. 


\title{
Ammonite stratigraphy and the belemnite genus Hibolithes in the higher Serdj Formation (Aptian-Albian boundary interval) in north central Tunisia
}

\author{
Jens Lehmann¹, Ekbert Seibertz², Christian Spaeth ${ }^{3}$ \& Luc G. Bulot ${ }^{4}$ 5* $^{*}$
}

Lehmann, J., Seibertz, E., Spaeth, C. \& Bulot, L.G. (2020): Ammonite stratigraphy and the belemnite genus Hibolithes in the higher Serdj Formation (Aptian-Albian boundary interval) in north central Tunisia. - Z. Dt. Ges. Geowiss.

\begin{abstract}
The identifications of some ammonite findings from the Aptian-Albian boundary interval of the type locality of the Serdj Formation at Djebel Serdj in north central Tunisia are revised and their biostratigraphic value is discussed. From this stratigraphic section, a single belemnite finding is described that has been previously identified as Neohibolites. A newly prepared thin section of the guard shows the internal structure of rostrum and phramoconus, including some septa, and allows an assignment as Hibolithes cf. obtusirostris (Pavlow in Pavlow \& Lamplugh 1891). It represents the youngest record of this genus from the Tethys where the youngest record of Hibolithes was hitherto early Barremian. The new evidence is also of palaeobiogeographic interest, since Hibolithes is originally a genus of the Tethys, which migrated early into the Boreal and from there later on again into the Tethys.

Kurzfassung: Die Bestimmung einiger Ammonitenfunde aus dem Grenzbereich Aptium/Albium der Typlokalität für die Serdj-Formation am Djebel Serdj in nord-zentral Tunesien werden revidiert und ihre biostratigraphische Aussage diskutiert. Aus diesem stratigraphischen Abschnitt wird ein bislang als Neohibolites bestimmter einzelner Belemnitenfund beschrieben. Ein neu angefertigter Dünnschliff zeigt den internen Aufbau von Rostrum und Phragmokon, inklusive einiger Septen, und ermöglicht die Bestimmung als Hibolithes cf. obtusirostris (Pavlow in Pavlow \& Lamplugh 1891). Der Fund ist der jüngste dieser Gattung aus der Tethys, aus der Hibolithes bislang nur bis in das frühe Barremium bekannt war. Der neue Nachweis ist auch paläobiogeographisch interessant, da Hibolithes ursprünglich eine Gattung der Tethys ist, die früh in das Boreal migrierte und später zurück in die Tethys einwanderte.
\end{abstract}

Keywords: biostratigraphy, Lower Cretaceous, Aptian-Albian boundary interval, ammonites, belemnites, Hibolithes, Tunisia

Schlüsselwörter: Biostratigraphie, Unterkreide, Aptium/Albium-Grenzbereich, Ammoniten, Belemniten, Hibolithes, Tunesien

\section{Introduction}

During the last fifteen years, Aptian (Lower Cretaceous) carbonate deposits of the Serdj Formation at its type locality Djebel Serdj, north central Tunisia (Figs. 1 and 2) were studied by Tunisian, French and German geologists in detail with regard to lithology, lithostratigraphy, biostratigraphy (mainly ammonites), chemostratigraphy (including isotopic stratigraphy), and microfacies (Heldt et al. 2008, 2010; Lehmann et al. 2009; Ben Chaabane et al. 2019). These data were used for international correlation of these Tunisian successions (Weiß 2012; Núnez-Useche et al. 2014) and allow to reconstruct the palaeoenvironmental evolution of a south-Tethyan carbonate platform margin and to investigate its response to global climate change. The unusually 600 metres thick deposits consist of limestones, marlstones and siltstones, suggesting an accumulation in mid- and inner-ramp positions. The hermatypic platform biota in these deposits induce a

\footnotetext{
*Addresses of the authors:

${ }^{1}$ Geosciences Collection, Faculty of Geosciences, University of Bremen, Klagenfurter Str. 4, 28359 Bremen, Germany (jens. lehmann@uni-bremen.de)

${ }^{2}$ Institute of Geoecology, Technical University of Braunschweig, Langer Kamp 19c, 38106 Braunschweig, Germany (e.seibertz@, web.de)

${ }^{3}$ Institute of Geology and Palaeontology, University of Hamburg, Bundesstr. 55, 20146 Hamburg, Germany (chspaeth@web.de)

${ }^{4}$ Aix-Marseille Université, CNRS, IRD, INRA, Collège de France, Cerege, Site Saint-Charles, Case 67, 3, Place Victor Hugo, 13331 Marseille Cedex 3, France (bulot@cerege.fr)

${ }^{5}$ University of Manchester, School of Earth and Environmental Sciences, North Africa Research Group, M13 9PL Manchester, UK (luc.bulot@manchester.ac.uk)
} 


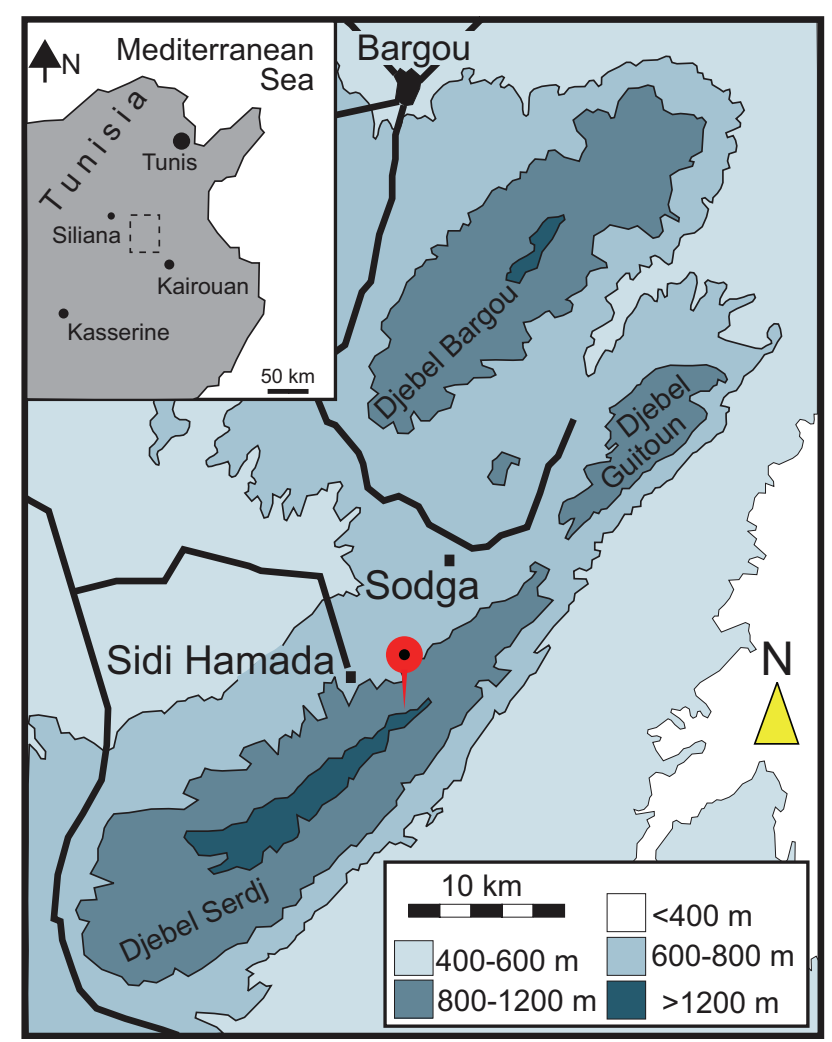

Fig. 1: Main study area at Djebel Serdj as part of the Serdj-Bargou anticline in north central Tunisia, with villages and the sampling locality of the described ammonites and belemnites.

stable oligotrophic water regime. Stable isotopes show a mid-late Aptian warming phase corresponding to siliciclastic limestones and siltstones, resulting rather from higher precipitation rates and intensified weathering, presumably of the southeasterly situated Kairouan Island and the southerly Kasserine Island, than from a drowning episode (Heldt et al. 2010).

\section{Geologic setting}

During Cretaceous times, Tunisia formed part of the NorthAfrican epicontinental border, and the southern part of the Tethys, respectively. Trans- and regression cycles can be combined in the Lower Cretaceous into four megasequences (Burollet et al. 1983: 263), the third of them comprises the time interval from the late early Aptian ("Gargasian") to the middle Albian. Dominated by the Kairouan and Kasserine islands in central Tunisia, this time interval is characterised by the following facies distribution (comp. Castany 1953: P1. III, VI and Burollet et al. 1983: Fig. 1): (1) sandstones and shallow marine carbonates as well as dolomites alternating with evaporites are found in south central and southern Atlas Tunisia (Orbata and Kebar formations; Trabelsi 2012) and the Chott regions (Berrani Formation; Hfaiedh et al. 2013); (2) extensive shallow marine carbonate deposits interfinger- ing with shales and sandstones (Hamada, Serdj, Hameima and Fahdene formations; Chihaoui et al. 2010; Latil 2011; Ben Fadhel et al. 2014), and lagoonal facies with coral-rudist reefal buildings dominantly in the salt dome zone (Serdj Formation; Lehmann et al. 2009; Heldt et al. 2010; Ben Chaabane et al. 2019) of northern Atlas Tunisia are recorded from $36^{\circ} \mathrm{N}$ (including the Serdj-Guitoun-Bargou ranges; Fig. 1) to about $34.15^{\circ} \mathrm{N}$ (Zaghbib-Turki 2003); (3) open marine/pelagic organic-rich shales intercalated with thin limestones containing planktic faunas (Fahdene and Bahloul formations; Soua 2016) are represented in northern Tunisia.

The Barremian Hamada Formation, as well as the Aptian-lower Albian Serdj Formation (informally subdivided as Lower Serdj and Upper Serdj by Ben Chaabane et al. 2019) crop out as a well exposed succession south of the town of Sidi Hamada (GPS Post Office: $35.96065^{\circ} \mathrm{N}$, $\left.9.54625^{\circ} \mathrm{E}\right)$ in the Serdj Mountain, which is the type locality for both formations (Fig. 2).

\section{Ammonites and biostratigraphy}

The Aptian ammonite fauna in north central Tunisia contains deshayesitids, pseudohaploceratids and hypacanthoplitids, and is, therefore, typical for the shelf environmental regions of the Tethys. This hemipelagic fauna shows affinities to faunas from the western and central Tethys as well as the Boreal region that was indistinctly defined compared to other stages of the Cretaceous (Lehmann et al. 2015). Ammonites with a supposed pelagic mode of life that occur in more distal Tethyan environments, such as lytoceratids, phylloceratids and heteromorphs, are a minor component, if present at all. In the late Aptian, large acanthohoplitids are found in inner ramp and lagoonal facies. Ammonites of this group are rare in the uppermost strata of Djebel Serdj (Heldt et al. 2010: 710); their poor preservation and importance in respect to the Aptian-Albian boundary interval are reasons why some identification were quite often debated. Latil (2011) and later partly Ben Chaabane et al. (2019, with Latil as a co-author) re-assigned some of the ammonites described originally by Lehmann et al. (2009) with partly contradictory results (Table 1). Furthermore, ammonite taxonomy is also difficult since parahoplitid ammonites (sensu lato) generally tend to be homoeomorphic and morphological differences are slight compared to other Cretaceous stages. Consequently, the identifications are briefly discussed in the following for the biostratigraphical dating of the belemnite specimen. The abbreviation GSUB refers to Geosciences Collection of the University of Bremen, Germany, and indicates the repository of specimens.

\subsection{Discussion of Mellegueiceras}

Mellegueiceras Latil (2011) is a hypacanthohoplitid ammonite that is an allegedly endemic genus from Tunisia that was recently also reported from Morocco (Luber et al. 2017, 2019). Since this genus is critical for the stratigraphical in- 


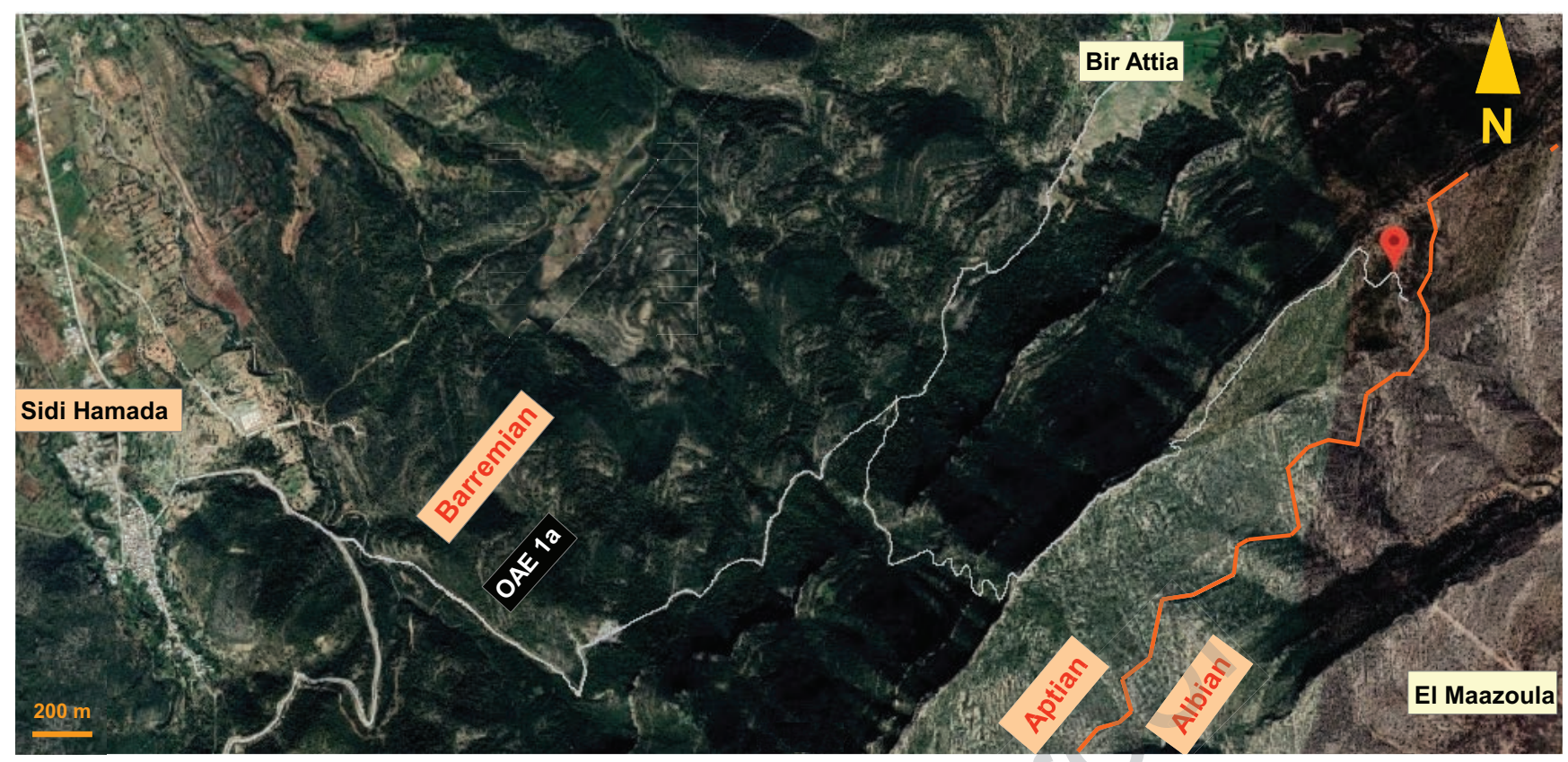

Fig. 2: Central part of Djebel Serdj, with the section trail from the town of Sidi Hamada to the top of the mountain range with the finding location of the belemnite (red point). The red line marks the Aptian-Albian boundary interval.

terpretation of the Aptian-Albian boundary interval in Tunisia, it is discussed here. Mellegueiceras was separated from Hypacanthoplites Spath, 1923 by "its irregular ribbing and the lack of tuberculation" according to Latil (2011: 371). Klein \& Bogdanova (2013: 208) question if Mellegueiceras should be regarded as a separate genus without discussing this issue any further.

The type species of Mellegueiceras, M. ouenzaensis, shows a somewhat irregular ribbing on the inner whorls only and this feature is not more irregularly developed compared to some Hypacanthoplites species referred to as $H y$ pacanthoplites. This is true for Hypacanthoplites elegans for example, with its neotype that is showing an irregularity between the bullae and a high variability in the number and height of onset of secondary ribs in between primary ribs. However, H. elegans is much more finely ornamented compared to the type species of Hypacanthoplites, Hypacanthoplites milletianus (d'Orbigny, 1841), and it remains unclear if species showing stronger ribbing or even strongly tuberculated inner whorls like H. plesiotypicus (Fritel 1906) can be reasonably placed in the same genus. Therefore, it possibly makes sense to accommodate $H$. elegans in $\mathrm{Mel}$ legueiceras.

The thickened ribs at the umbilical margin of the inner whorls in Mellegueiceras are very close to be called bullae and this is not clearly separating it from Hypacanthoplites. M. ouenzaensis can be separated from Hypacanthoplites though, by the inner whorls that are well-rounded and thus contrast the angular cross section seen in at least many wellknown European species of Hypacanthoplites. Other species of Mellegueiceras, M. hameimaense and M. minutum (both first described by Latil 2011), also show angular inner whorls and thus these features do not serve to distinguish both genera properly. "Melleguieiceras" chihaouiae appears to be quite different in cross section as well as ornament and rather resembles Hypacanthoplites than the type species of Mellegueiceras and the other species attributed to this genus. As an indication of uncertainty, we added quotation marks to the genus name herein.

A separation of Mellegueiceras from Parahoplites Anthula, 1900 is based on "ribs that are never bent forward on the venter, persistent irregular ribbing and wider umbilicus" following Latil (2011: 371). The first feature mentioned is not a criterion for exclusion and thus less advantageous for a distinction. It is believed to be a key feature to distinguish Parahoplites from acanthohoplids, but maybe this feature that is based on Parahoplites melchioris Anthula, 1900, is not strong enough to define Parahoplites in the current sense. Regarding to the second feature several Parahoplites species show an irregular ribbing (e.g. Parahoplites daveyi Casey, 1965 and Parahoplites irregularis Casey, 1965) and thus the irregularity of ribbing is not critical either. At last, a tendency to a more evolute coiling is developing within the Parahoplites, Acanthohoplites, Hypacanthoplites lineages during the late Aptian-early Albian and thus it does not constitute a unique feature as well.

This discussion shows that the definition of Mellegueiceras, Hypacanthoplites and Parahoplites is currently unsatisfying and that a new genus concept is needed. Furthermore, the affiliation of some species currently attributed to Hypacanthoplites and Parahoplites needs to be reviewed.

In the following the revised identifications of ammonites from the uppermost section at Djebel Serdj (section metres 810 to 835 ) given in Table 1 are discussed. 
Jens Lehmann et al.

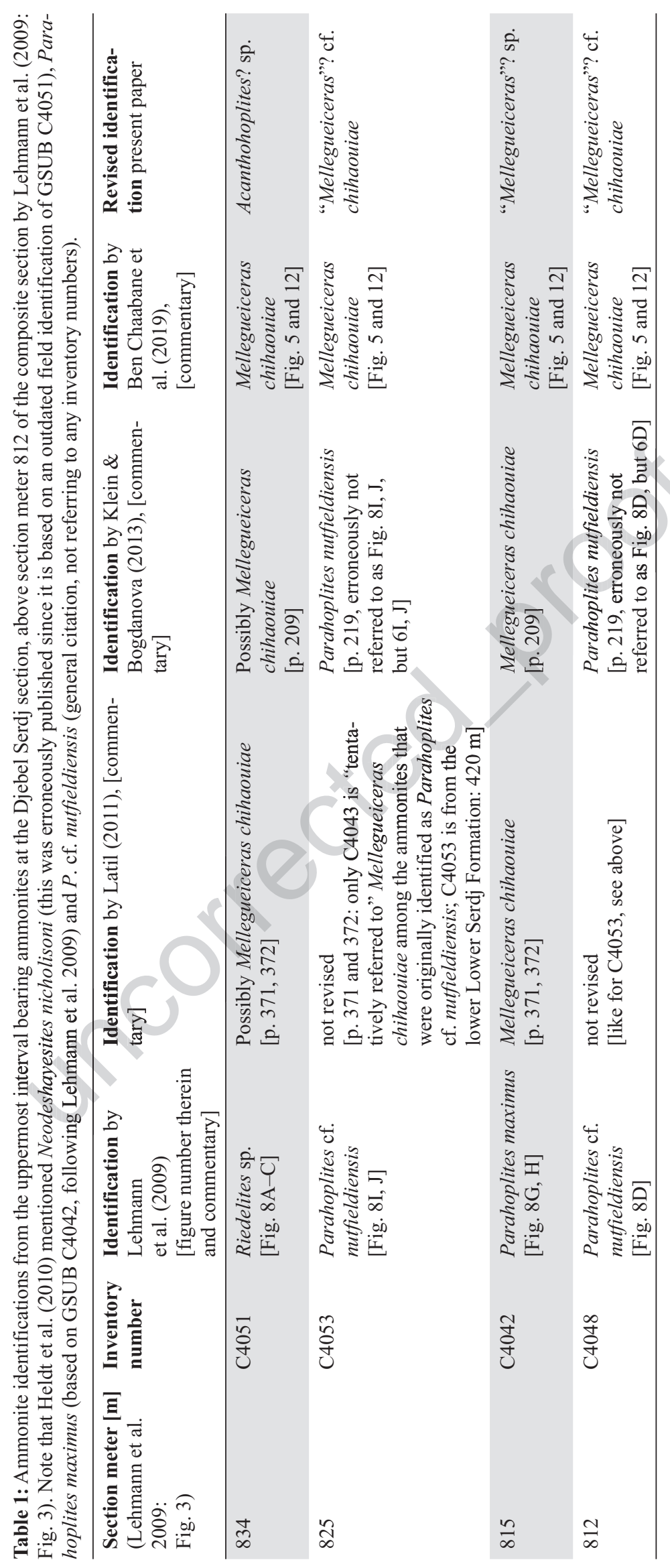




\subsection{Section metre 812: GSUB C4048}

Originally: Parahoplites cf. nutfieldiensis, revised: "Melleguieiceras"? cf. chihaouiae (Fig. 3H)

Latil (2011), Klein \& Bogdanova (2013) and Ben Chaabane et al. (2019) suggested to attribute some of the specimens figured as $P$. cf. nutfieldiensis by Lehmann et al. (2009) to "M." chihaouiae. After one of us (JL) was studying the type specimens of $P$. nutfieldiensis at the Natural History Museum (Lehmann et al. 2019: Supplementary Data Appendix B) we agree that the Tunisian specimen are not conspecific with $P$. nutfieldiensis. Based on the fairly open coiling and according to the ornament, it appears likely that they represent "Mellegueiceras". GSUB C4048 (Lehmann et al. 2009: Fig. 8D) as well as C4053 (Figs. 3D, E; Lehmann et al. 2009: Fig. 8I, J) are very poorly preserved and thus it is not convenient to determine them on the species level. The same is true for C4043 (Figs. 3I, J; Lehmann et al. 2009: Fig. 7I, J) from a lower level in the section.

The specimen C4048 shows simple, strong ribs and secondary ribs that do not arise before mid-flank and that are as strong as the primary ribs on the inner half of the flank. There is usually one secondary rib in between two primary ribs. This rib pattern contrasts the type material of $P$. nutfieldiensis from the Lower Greensand Group, but some new material at hand (Mark Bayliss collection, to be transferred to the Natural History Museum, London) from the same strata demonstrates a considerable variability. The coiling of C4048 appears to be more evolute than in P. nutfieldiensis and generally in Parahoplites and agrees with the re-identification given above.

A stratigraphic position as lowermost Albian and not upper Aptian (Latil 2011) is confirmed by data from Morocco where "Melleguieiceras" chihaouiae is associated with Douvilleiceras (Luber et al. 2017, 2019).

\subsection{Section metre 815: GSUB C4042}

Originally: Parahoplites cf. maximus, revised: "Mellegueiceras"? sp. (Figs. 3F, G)

This specimen is less distorted compared to the other specimens revised here. We orientate this fragment different from Lehmann et al. (2009) and the whorl section appears to be broadest around mid-flank and not near the umbilical rim. However, in our re-identification we disagree with the interpretation of Latil (2011), Ben Chabaane et al. (2019) and Klein \& Bogdanova (2013) that GSUB C4042 represents "Mellegueiceras" chihaouiae. It is different from the "M." chihaouiae macroconch of a similar size (Latil (2011: Pl. X and XI, 4), by a ribbing on the inner flank with ribs that are more distant and that are forming bullae on the very broad ribs. Near the umbilical edge the ribbing is generally reflecting backwards in GSUB C4042, leading to a rib style that is flexuous, as in the type of $P$. maximus, but even more distinct than in some of the specimens figured by Sinzow (1908: Pl. I, Fig. 3). In cross section, GSUB C4042 is much broader and less evenly rounded than "M." chihaouiae. The particularly strong umbilical bullae that are bending forward on the lowermost flank, and then very strongly forwards again, is also present in acanthohoplitids. A similar ribbing pattern can be seen in some latest Aptian acanthohoplitids, e.g. in mid-size specimen figured by Sinzow (1908: Pl. VIII, Figs. 8 and 11). They are referred to as Nolaniceras spp. by Klein \& Bogdanova (2013), a view that is not followed by Bulot et al. (2014): according to these authors, Nolaniceras is strictly defined to the holotype of the type species. It is also true for the paratype of Acanthohoplites aschiltaensis Anthula (1900: Pl. XI, Fig. 1), but also in ?Parahoplites tenuicostatus (Sinzow 1908: Pl. VII, Fig. 2). The exact stratigraphic assignment of the latter species is unclear and thus it is unknown if this feature is of stratigraphic relevance (compare Szives et al. 2007: 72).

\subsection{Section metre 825: GSUB C4053}

Originally: Parahoplites cf. nutfieldiensis, revised: "Melleguieiceras"? cf. chihaouiae (Figs. 3D, E)

The ribs of specimen $\mathrm{C} 4053$ are all of equal strength, more delicate than in $\mathrm{C} 4042$ (Figs. 3F, G) described above and also finer than in $\mathrm{C} 4043$ (all referred to as $P$. cf. nutfieldiensis by Lehmann et al. 2009, but with C4053 from a much lower stratigraphic level). C4053 agrees with the other specimens identified earlier as $P$. cf. nutfieldiensis in showing one secondary rib in between two primary ribs only. The poor preservation permits only to assume that the secondary ribs arise probably as low as at mid-flank and that the cross segment is very well-rounded probably shows the greatest whorl breadth around mid-flank.

Except for the finer ribbing, the features of $\mathrm{C} 4053$ also distinguish it from the type material of $P$. nutfieldiensis (compare 3.2). We disagree with Klein \& Bogdanova (2013) who assigned this specimen to $P$. nutfieldiensis (omitting the "cf." by Lehmann et al. 2009), but agree with the re-identification of Latil (2011).

\subsection{Section metre 834: GSUB C4051}

Originally: Riedelites sp., revised: Acanthohoplites? sp. (Figs. 3A-C)

The worn and distorted fragment was originally assigned to Riedelites because it recalls the type of Parahoplites inconstans (Riedel 1938: Pl. 6, Figs. 8-10; now Riedelites inconstans; see Klein \& Bogdanova 2013: 151), by its prominent and distant ribs and particularly "the large smooth areas on the inner flank between primary ribs", and the secondary ribs that do not arise before a high position on the flank (Lehmann et al. 2009: 907). Despite these similarities with the type of Riedel (1938), as well as the other material referred to Riedelites (e.g. Etayo-Serna 1979; Sharikadze et al. 2004), we revise the initial identification here. The Tunisian specimen shows extremely strong umbilical bullae and even a more robust ribbing.

A similar morphology compared to GSUB C 4051 shows also Parahoplites robustus Sinzow, 1908, a species that is of 


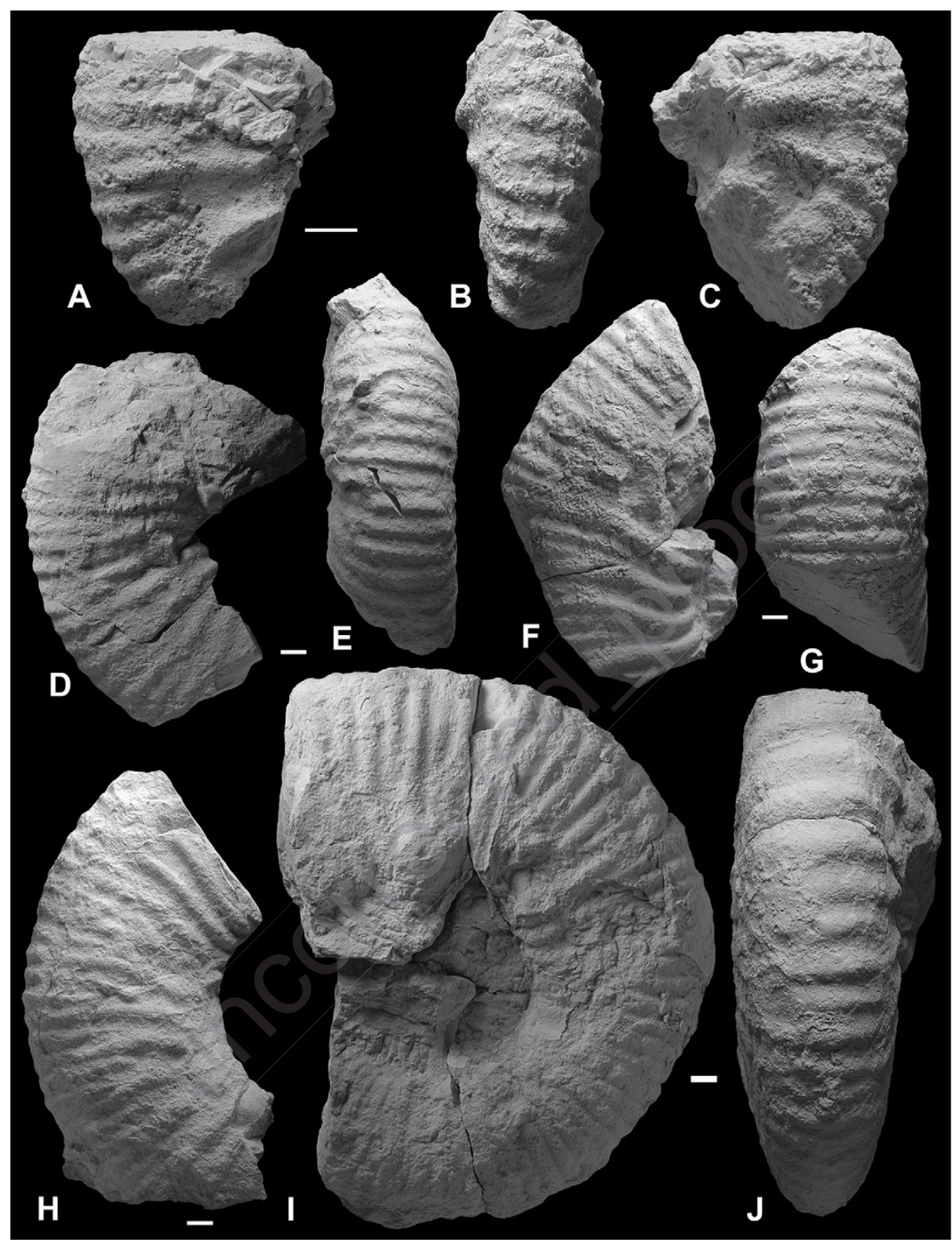

Fig. 3: Ammonite records from Djebel Serdj, northern Tunisia. (A-C) Acanthohoplites? sp., GSUB C4051. (D, E) "Mellegueiceras"? sp., GSUB C4053. (F, G) "Mellegueiceras"? sp., GSUB C4042. (H) "Mellegueiceras"? cf. chihaouiae, GSUB C4048. (I, J) "Mellegueiceras"?, GSUB C4043. Scale bar $10 \mathrm{~mm}$. 
unknown detailed stratigraphic occurrence, but the bullae are even more distant in the Tunisian specimen. In this aspect, it resembles Mellegueiceras hameimaense of Latil (2011) in which the bullae appear to be closer to each other. GSUB C 4051 is not conspecific with the material attributed to " $M$." chihaouiae Latil (2011) as suggested by Latil (2011: 371, 372 ) as well as by Klein \& Bogdanova (2013), because of its pronounced and particularly very distant umbilical bullae without any ribs in between - an ornament unlike that of juvenile representatives of "M." chihaouiae. We place GSUB C 4051 into acanthohoplitids because it is similar in showing distant umbilical bullae although representatives of these usually contrasts by secondary ribs that are also present in between the umbilical bullae and are mostly not smooth in between as seen the GSUB C4051.

\subsection{Discussion of the geological age}

Based on the revised ammonite record from section metres 812 to 834 we interpret that the dating of this part of the Djebel Serdj section by Lehmann et al. (2009) is probably slightly too old.

As already stated by Szives et al. (2007) the "stratigraphical distribution of Parahoplites, and also the co-occurrence with Acanthohoplites and Hypacanthoplites is problematic" and Owen (1996) states that the upper limit of Parahoplites falls together with the occurrence of Hypacanthoplites in the Late Aptian Nolaniceras nolani Zone that is debated though (Casey 1996). Szives et al. (2007) suggested that Acanthohoplites, Hypacanthoplites and Parahoplites are partly cooccurring in northern Iran interpreting Raisossadat (2006). This interpretation might be partly based on general statements of ammonite occurrence but no detailed ranges are given by Raisossadat (2006). Probably only Acanthohoplites and Parahoplites co-occur (cf. Raisossadat 2006: Fig. 2). The results of the most recent paper on this topic also did not find evidence for a co-occurrence of Acanthohoplites, Hypacanthoplites and Parahoplites (Lehmann et al. 2019). At least it is clear that acanthohoplitids overlap with Hypacanthoplites and Parahoplites based on the record in Iran (Lehmann et al. 2019).

Out of this discussion the taxonomic re-interpretations of the individual ammonite record from section metres 812 to 834 by Klein \& Bogdanova (2013) is problematic from a stratigraphic point of view. If GSUB C4048 (Fig. 3H) is interpreted an unequivocal representative of $P$. nutfieldiensis, as done by these authors, the index of the $P$. nutfieldiensis Zone of the middle upper Aptian would co-occur with latest Aptian or earliest Albian ammonites ("M." chihaouiae).

The critical interval belongs to the T4 and $\mathrm{Cu} 5$ units of Ben Chaabane et al. (2019), attributed to the "M." chihaouiae Zone sensu Latil (2011). This zone is not well-dated in Tunisia, further index ammonites are missing. An alleged condensation by "reworked phosphatised Epicheloniceras" (Latil 2011: 372), respectively "Reworked, phosphatised, juvenile Epicheloniceras sp.“ (Ben Chaabane et al. 2019: 588) is actually based on a misidentification. These reported che- loniceratids are actually douvilleiceratids, possibly of a hitherto new genus (pers. obs. by one of us: LGB). However, although it remains uncertain if it represents latest Aptian or earliest Albian sediments from the Tunisian record (compare Ben Chaabane et al. 2019: Fig. 17) the association of " $M$." chihaouiae with Douvilleiceras in Morocco places it into the Albian (Luber et al. 2017). Nevertheless, our revised dating is in accordance with the interpretation of the T4 and $\mathrm{Cu} 5$ units as "Aptian-Albian transition" by Ben Chaabane et al. (2019) and places the uppermost faunal horizon of Lehmann et al. (2009) probably into the earliest Albian (comp. Figs. $4 \mathrm{~A}$ and $\mathrm{B})$.

\section{The belemnite findings}

\subsection{Belemnites in the southwestern Tethys}

Belemnites are generally rare findings in the northwest African Lower Cretaceous, except in some few layers. In the north-Tethyan regions from the Vocontian Basin in southeast France to the Betic Cordillera in southeast Spain, they are known to be common (see Janssen et al. 2012 with references herein). Contemporaneous beds in the western High Atlas of Morocco contain lots of belemnites, so that these beds can be characterised by belemnite assemblages similar to those of France and Spain (Mutterlose \& Wiedenroth 2008). One of the first who investigated northwest African Lower Cretaceous belemnites and used them for biostratigraphy was Coquand (1862: 27, 28), characterising in the Algerian region of Constantine an "Étage néocomien caractérisé par les Belemnites dilatatus Blainv." (corresponding to Duvalia dilatata of the Hauterivian), and an "Étage aptien caractérisé par le Belemnites semi-canaliculatus Blainv." (corresponding to Mesohibolites semicanaliculatus of the Aptian). South of Constantine, Peron (1889-90: 1) found "les Belemnites latus, B. bipartitus, etc. dans les marnes néocomien" in the Batna region (corresponding to Duvalia lata Blainville, and Pseudobelus bipartitus Blainville of the Valanginian-Hauterivian interval). Gentil (1902: 192, 193) found in the Tafna Basin of central Algeria "Pseudobelus bipartitus Blainv." and "Duvalia dilatata d'Orb." from the Hauterivian at Arlal, and "Hibolites sp." and "Duvalia Grasi Duv. sp." from the Barremian of the same location.

\subsection{The Djebel Serdj belemnites}

Pervinquière (1903: 41) described the section of the Djebel Serdj in detail giving lists of fossils for every lithological unit but without belemnites. In fossil-lists of the neighbouring Djebel Bargou and Djebel Guitoun (comp. Fig. 1), Pervinquière (1903: 45, 46) cited "Belemnites (Hibolites) semicanaliculatus Blainv." which is now Mesohibolites semicanaliculatus (de Blainville 1827). Four years later, Pervinquière (1907: 403 ff.) described a lot of belemnites from the Tunisian Lower Cretaceous that belong to the genus Duvalia (5 species), Pseudobelus (1 species) and Hibolithes (9 species). 


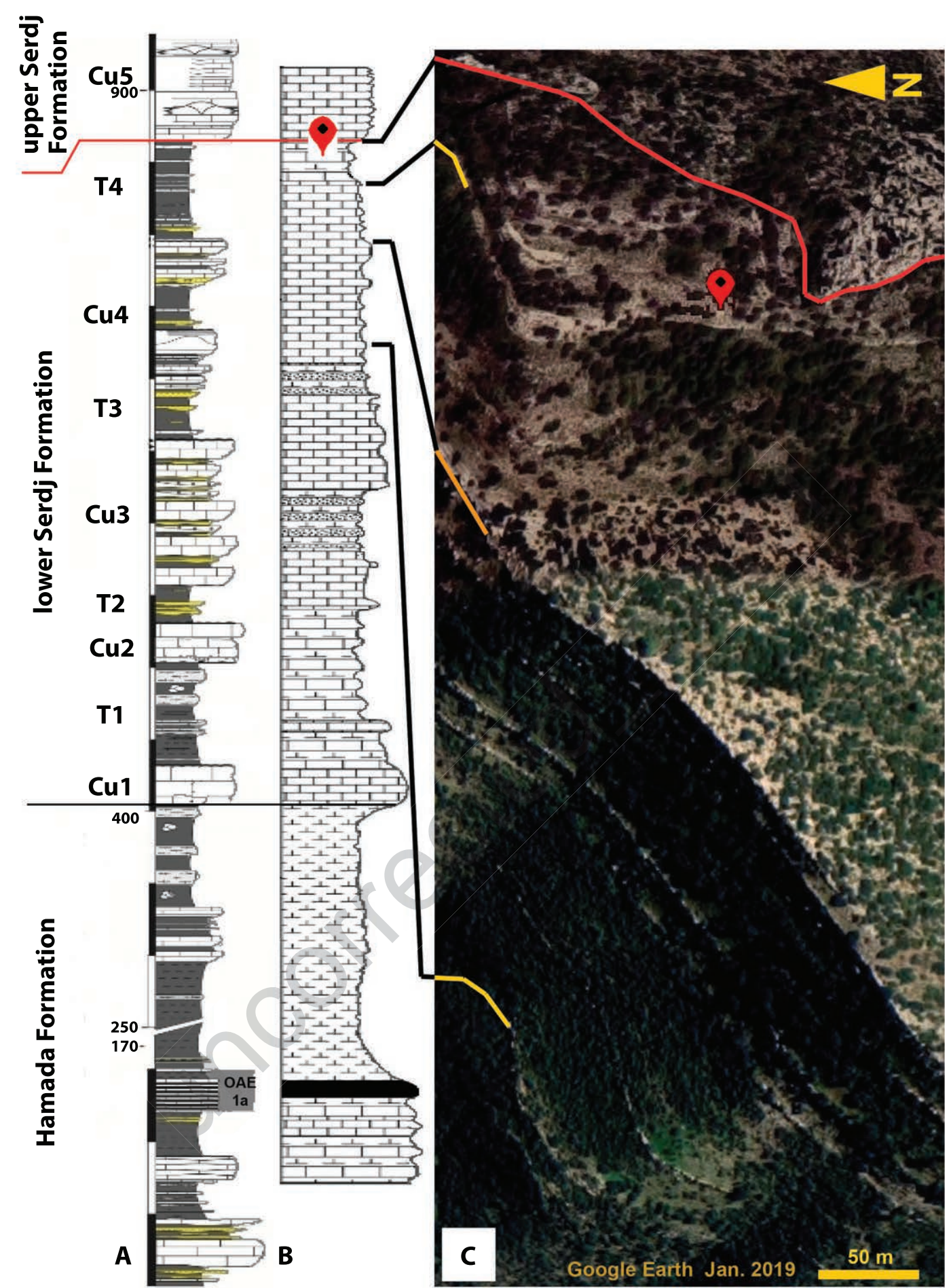

Fig. 4: Correlation of the composite sections of (A) Ben Chaabane et al. (2019: Fig. 5), (B) Lehmann et al. (2009: Fig. 3), and (C) Google Earth map with the position of the belemnite finding. The red line between T4 and Cu5 marks the Aptian-Albian boundary interval, the red point the belemnite. Scale bar aside section $\mathrm{A}$ is equal to that in section $\mathrm{B}$. 
From the latter genus, only one species remains today in the genus concept of Hibolithes, the other species are representatives of the genus Mesohibolites and Neohibolites. Castany (1951: 31) cited from the Djebel Serdj "Belemnopsis semicanaliculatus Blainv.", which is nowadays Mesohibolites semicanaliculatus (de Blainville 1827), a form with great affinities to our finding. Since then, belemnites are recorded only as "belemnites" or "rostra" (e.g. Ben Fadhel et al. 2011) or even only as symbols aside a lithostratigraphic column (e.g. Latil 2011).

\subsection{The GSUB C4049 belemnite}

The belemnite GSUB C4049 from section metre 828 of the composite section of Lehmann et al. (2009; Fig. 3; GPS North $35.96674^{\circ}$, East $009.59452^{\circ}$ ) was neither figured nor described, but is the specimen referred to as Neohibolites sp. in their range chart, and also mentioned on their p. 901-903 and their Table 1. It was also mentioned by Heldt et al. (2010: Table 1) and comes from the uppermost part of the outcrop of the Serdj Formation at its type locality at Djebel Serdj (Fig. 4C) in north central Tunisia. Originally this stratigraphic interval was placed into the middle upper Aptian based on the ammonite records of Parahoplites cf. nutfieldiensis, Parahoplites maximus and Riedelites in between section metres 810 to 835 (Lehmann et al. 2009: Fig. 2), are herein revised (Table 1). This stratigraphic interval (Figs. 4A and B) is now placed into the highest upper Aptian or lowermost Albian.

\subsubsection{Description}

Order Belemnitida Macgillivray, 1840

Suborder Pachybelemnopseina Riegraf, 1998

Family Mesohibolitidae Nerodenko, 1983

Genus Hibolithes Denys de Montfort, 1808

Hibolithes cf. obtusirostris (Pavlow in Pavlow \& Lamplugh, 1891)

Figs. 5B, 6A-F

Comments to the species authorship: The Imperial Society of Naturalists of Moscow published their Bulletin quarterly. The article of the two authors about the Speeton Clay and their Russian equivalents appeared in four parts: introduction by both authors, geology of the Speeton Clay by Lamplugh, belemnites by Pavlow and ammonites by Pavlow. The first three parts appeared in the double-number $2 \& 3$ delivered in September 1891, the fourth part in December 1891. The cover for the whole volume was published in the first quarter of the next year, which is 1892 . Therefore, the authorship has to be cited as "Pavlow 1891" or "Pavlow in Pavlow \& Lamplugh, 1891".

Description: The short but effective diagnosis of the species made by Pavlow (1891: 262-263, Pl. VII, Fig. 7) as well as the detailed new description of Swinnerton (1952: 61-62, P1. XVI, Figs. 3-7) allowed an unreserved definition - the use of open nomenclature is due to the fact that no external features are to be seen. A preparation of the rostrum was not possible because of the hardness of the limestone around it. So, most of the features for identifying are from a thin section. In the following, the rostral nomenclature is adopted from Spaeth (1971) (comp. Fig. 5A).

The belemnite finding is a slightly eroded rostrum with an elongated outline (Fig. 6A). The apical line is straight and central (Figs. 5B and 6B, C). A short peak is preserved (Fig. $6 \mathrm{~A})$, which lies centrally without forming a distinct mucro. The alveolar angle is 17 degrees, which coincides with data from Pavlow (1891: 262) and Spaeth (1989: 79). The protoconch is overgrown by calcite. This coarse-grained overgrowth is induced by a ventral furrow at the alveolar end (comp. Fig. 6G) which is a third of the orthorostrum. Therefore, the view has to be perpendicular to the dorsoventral plain, which means it is a lateral view. The minimal thickness Dmin (blue line in Fig. 5B) shifts ontogenetically to the alveolus, whereas the maximal thickness Dmax (red line in Fig. 5B) remains more or less at one point of the rostrum, the ratio Dmax/Dmin has a constant value of 1.5, comparable to some specimens from the Isle of Heligoland (according to unpublished data by one of us: CS). The reason for this Dmax position is a reduced growth of the length in relation to thickness and breadth during ontogeny. Therefore, the apical part becomes more obtuse, shown in Fig. 5C by a striking bend in the graph. The Tunisian form is smaller compared to those from the Isle of Heligoland (Spaeth 1989) or the Speeton Clay (Swinnerton 1952), but the congruence of the bluecircle graph and the green-square graph shows that the Tunisian form is an adult specimen. Fig. 6B shows the thin section in incident light with dark background, so that mineral overgrowth is visible very well: besides the calcite of the ventral furrow, bright points of calcification are visible in the rostrum. Fig. $6 \mathrm{C}$ is the thin section seen in transmitted light. The calcitic rostrum of the guard shows only little diagenetic overgrowth because the accretion lines are visible excellently. In Fig. 6D, the area of the peak is enlarged to show an offspring, presumably the first chambers of a bryozoan colony. This means that the rostrum was exposed at the sea bottom for only short time before it was covered by carbonate mud. Fig. 6E shows the section of the rostrum after the sawing of the thin section. The plane of intersection cuts here the siphuncle, which was filled by carbonate mud. In spite of the coarse-grained calcitic filling of the phragmoconus, segmentation into eight chambers is still visible. Fig. $6 \mathrm{~F}$ is a magnification of part of the phragmoconus with the siphuncle and the alveolar wall, which shows a slight undulation because of the roundness of the chambers (comp. Doguzhaeva \& Melendez 2017: Fig. 9). For comparison with older Early Cretaceous Hibolithes species, two sketches of the typical Hauterivian-Barremian H. jaculoides Swinnerton, 1937 are given in Figs. 6G and H. Fig. 6G is a ventral side with typical slender alveolar end and a ventral furrow, Fig. $6 \mathrm{H}$ is a lateral sight with a typical peeling of the alveolar end. 

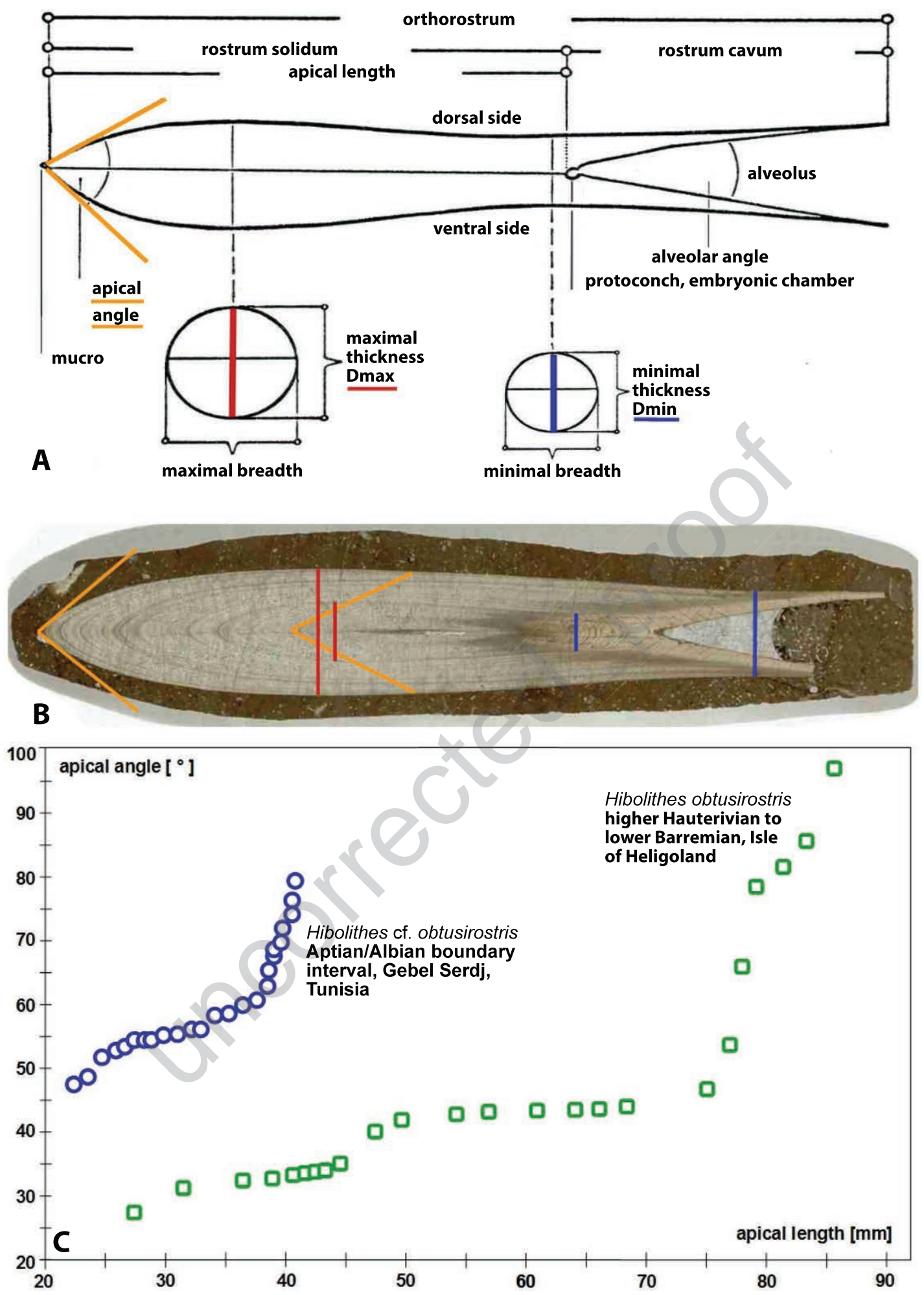

Fig. 5: (A) Sketch of a belemnite guard with the main features important for identification (redrawn from Spaeth 1971). (B) Thin section of the described belemnite with position of features and dimensions mentioned in the text (lateral section, comp. Fig. 6C). (C) Graphic description of the ontogenetic changes of the apical angle in relation to the apical length. Blue-circle graph comprises data from the Tunisian belemnite (specimen GSUB C4049), green-square graph from a specimen from the Isle of Heligoland (redrawn and completed from original material of Spaeth 1989). 

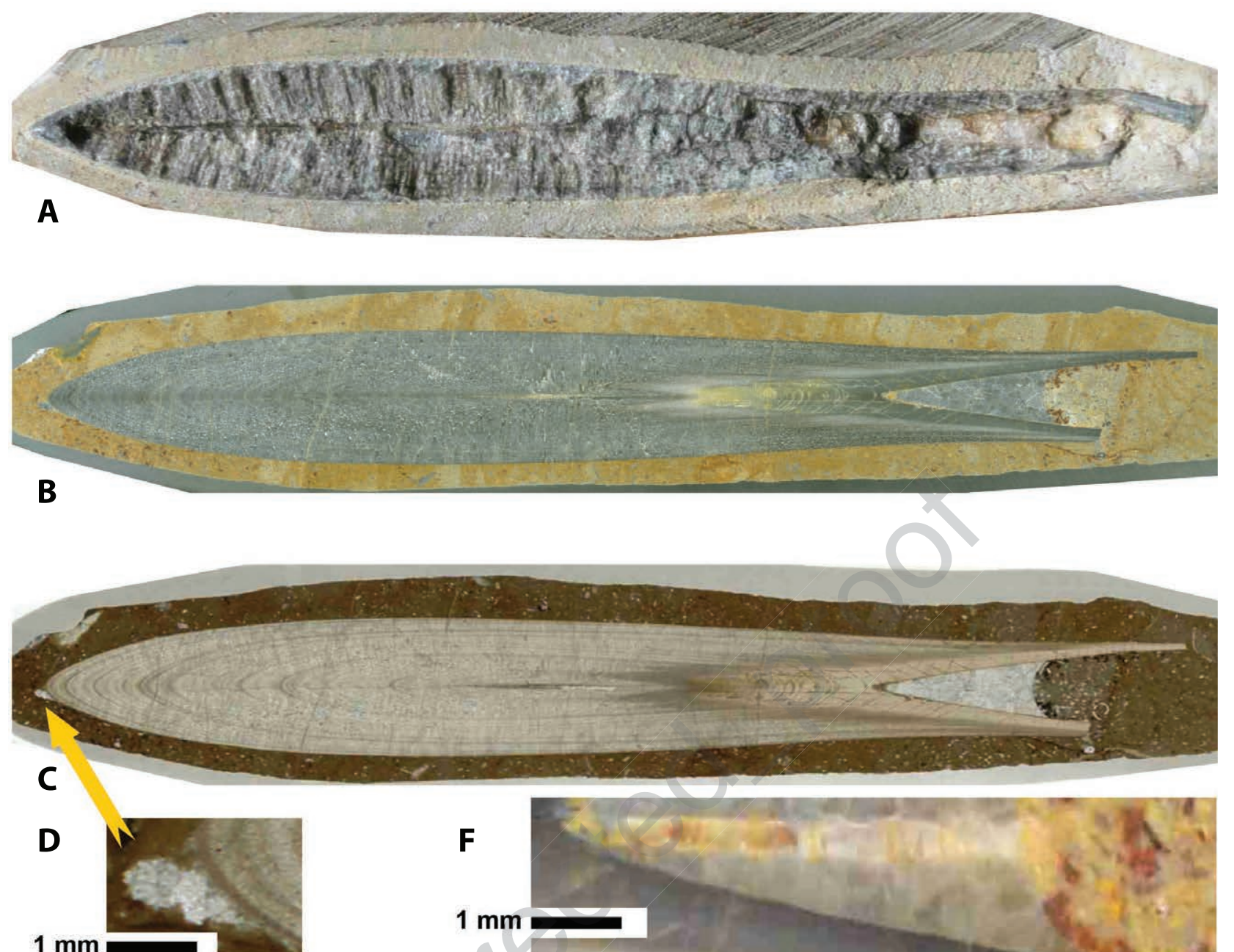

$1 \mathrm{~mm}$
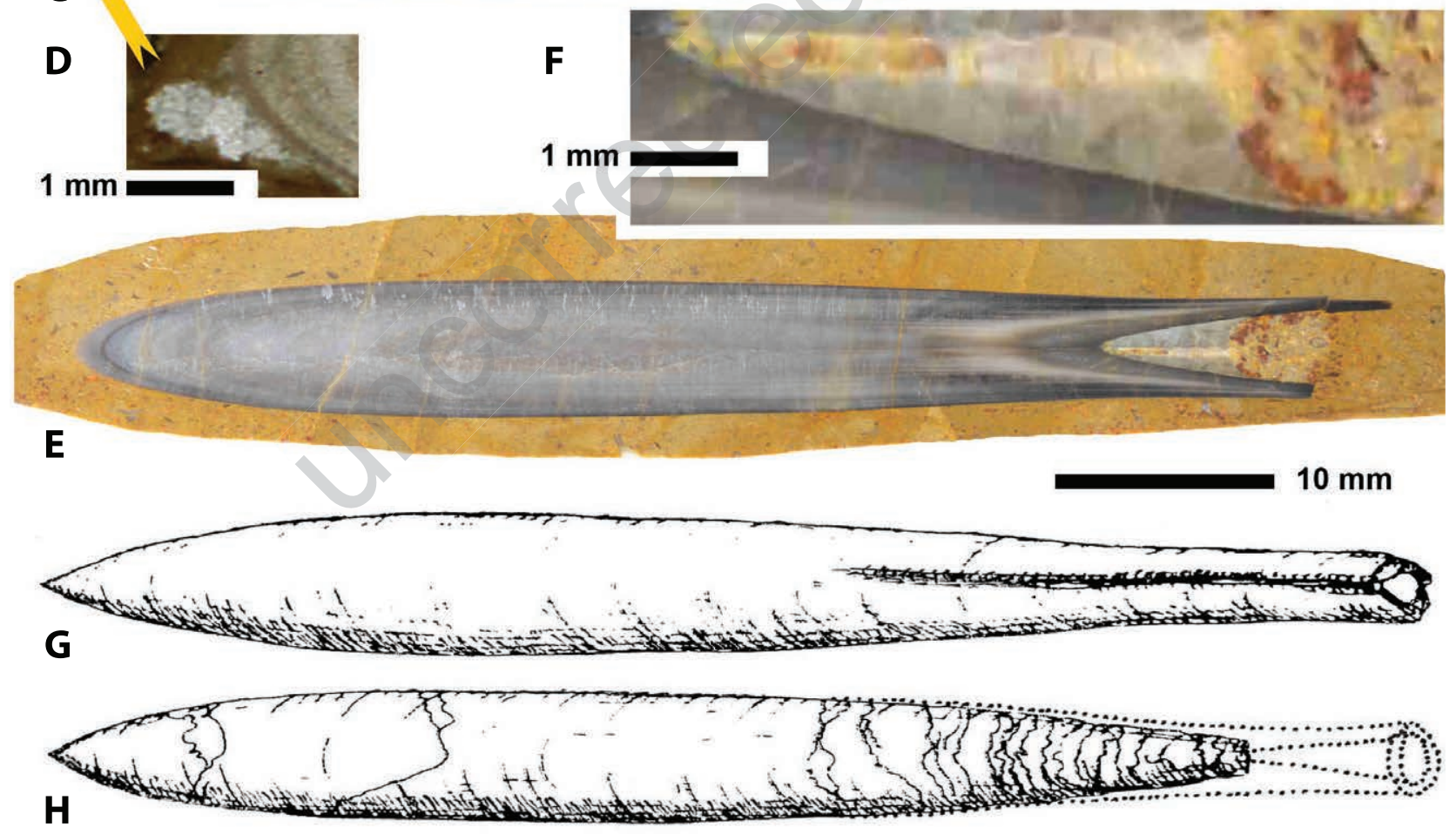

Fig. 6: Hibolithes cf. obtusirostris (Pavlow in Pavlow \& Lamplugh 1891) (specimen GSUB C4049 from Djebel Serdj, northern Tunisia (A-F) and sketches of Hibolithes jaculoides $(\mathrm{G}, \mathrm{H})$ for comparison. (A) Original sight of the belemnite finding, lateral section. (B) The thin section in incident light with dark background, lateral section. (C) Thin section seen in transmitted light, lateral section. (D) Area of the peak, enlarged to show an offspring (bryozoan?). (E) Section of the rostrum after the sawing of the thin section, lateral section. (F) Magnification of part of the phragmoconus with the siphuncle. (G) Sketch of Hibolithes jaculoides, showing the ventral side with typical slender alveolar end and a ventral furrow. (H) Sketch of Hibolithes jaculoides in lateral sight with a typical peeling of the alveolar end. The scale bar represents $10 \mathrm{~mm}$ and is valid for all rostra. 


\subsubsection{Discussion of taxonomy and palaeobiogeography}

Though the outer diagnostic features of the belemnite cannot be seen, various measurements and internal features discussed in the previous chapter lead to the determination as Hibolithes cf. obtusirostris (Pavlow in Pavlow \& Lamplugh, 1891). The co-occurring Mesohibolites semicanaliculatus (de Blainville, 1827) (see chapter 4.2) is less elongate/more stout and less obtuse with a distinct mucro and a greater alveolar angle. Some neohibolitids with obtuse ends similar to the Tunisian specimen, e.g. Neohibolites minimus obtusus Stolley, 1911 (comp. Spaeth 1971: 62), are smaller, show a different apical angle graph and are of middle Albian age.

The stratigraphic position of latest Aptian-earliest Albian (see chapter 3.6) is very young and hitherto unknown for this genus for the Tethys; the youngest specimens of Hibolithes are known from Tethyan occurrences of Early Barremian age (e.g. Janssen 1997; Janssen \& Fözy 2003). In contrast to this, from Boreal localities (e.g. northern Germany) Hibolithes is known from Aptian sediments, too (Stolley 1911; Mutterlose et al. 1983; Spaeth 1989 and references therein). Under palaeobiogeographic aspects, the originally Tethyan belemnite genus Hibolithes was able to migrate early into the Boreal regions as well as re-migrated later on into Tethyan areas again (Stevens 1973; Mutterlose et al. 1983). This scenario was repeated by Upper Cretaceous belemnitellids, as they also immigrated occasionally into northern Tethyan margins (Christensen 1997).

\section{Acknowledgements}

We thank Ralf Bätzel (Bremen) for making the thin section of the belemnite specimen. Markus Wilmsen (Dresden) and Hugh G. Owen (London) kindly discussed some ammonite identifications and Matthias Heldt (Emden) the stratigraphy of the Djebel Serdj section. Jean-Louis Latil (Lazer) kindly provided some original figures of his publications. This research is based on material collected in the year 2006 with support of the DFG (German Research Foundation, project no Ba-1571-1-1). We thank Jörg Mutterlose (Bochum) as well as Martin Košt'ák (Prague), for valuable hints and their critical reviews and Markus Wilmsen for his careful editorial work.

\section{References}

Anthula, D.J. (1900): Über die Kreidefossilien des Kaukasus mit einem allgemeinen Ueberblick über die Entwicklung der Sedimentärbildungen des Kaukasus. - Beitr. Paläontol. Geol. Österr.-Ungarns u. d. Orients, 12: 55-159.

Ben Chaabane, N., Khemiri, F., Soussi, M., Latil, J.-L., Robert, E. \& Belhajtaher, I. (2019): Aptian-Lower Albian Serdj carbonate platform of the Tunisian Atlas: Development, demise and petroleum implication. - Mar. Pet. Geol., 101: 566-591.

Ben Fadhel, M., Layeb, M., Hedfi, A. \& Ben Youssef, M. (2011): Albian oceanic anoxic events in northern Tunesia: Biostrati- graphic and geochemical insights. - Cretaceous Res., 32: 685699.

Ben Fadhel, M., Zouaghi, T., Amri, A. \& Ben Youssef, M. (2014): Radiolarian and planktic foraminifera biostratigraphy of the Early Albian organic rich beds of Fahdene Formation, northern Tunisia. - J. Earth Sci., 25 (1): 45-63.

Bulot, L.G., Latil, J.-L., Hairabian, A. \& Fournillon, A. (2014): New insight on the genus Nolaniceras Casey, 1961 (Ammonoidea, Cretaceous) and its consequences on the biostratigraphy of the Aptian Stage. - Proc. Geol. Assoc., 125 (2): 227-232.

Burollet, P.F., Memmi, L. \& M'Rabet, A. (1983): Le Crétacé inférieur de Tunisie. Aperçu stratigraphique et sédimentologique. - Zitteliana, 10: 255-264.

Casey, R. (1965): A monograph of the Ammonoidea of the Lower Greensand, part VI. - Paleontograph. Soc. Monogr., 118 (1964): 399-546.

Casey, R. (1996): Lower Greensand ammonites and ammonite zonation. - Proc. Geol. Assoc., 107: 69-74.

Castany, G. (1951): Ètude géologique de l'Atlas Tunisien oriental. - Ann. Mines Géol., 8: 1-633.

Castany, G. (1953): Carte géologique de la Tunisie au 1: 500.000 . Notice explicative: 143 p.; Tunis (S.E.F.A.N.).

Chihaoui, A., Jaillard, E., Latil, J.-L., Zghal, I., Susperregui, A.-S., Touir, J. \& Ouali, J. (2010): Stratigraphy of the Hameima and lower Fahden formations in the Tadjerouine area (northern Tunisia). - J. Afr. Earth Sci., 58 (2): 387-399.

Christensen, W.K. (1997): Palaeobiogeography and migration in the Late Cretaceous belemnite family Belemnitellidae. - Acta Palaeontol. Pol., 42 (4): 457-495.

Coquand, H. (1862): Géologie et paléontologie de la région sud der la province de Constantine. - Mém. Soc. Émulat. Provence, 2: 1-342.

De Blainville, H.M.D. de (1825-1827): Manuel de malacologie et de conchyliologie: 1-664 (1825), P1. 1-87 (1827); Paris (Levrault).

Denys de Montfort, P. (1808): Conchyliologie systématique et classification méthodique des coquilles, 1: $86+409$ p.; Paris (Schoell).

Doguzhaeva, L.A. \& Meléndez, G. (2017): The embryonic conch structure as a supposed imperative factor on the hatchling dispersal and geographical expansion of belemnites: An example of Callovian (Middle Jurassic) pachybelemnopseins from Aragón (NE Spain). - N. Jb. Geol. Paläont. Abh., 283 (3): 317 334.

D’Orbigny, A. (1841): Paléontologie française: Terrains crétacés. 1. Céphalopodes: 121-430; Paris (Masson).

Etayo-Serna, F. (1979): Zonation of the Cretaceous of central Colombia by ammonites. - Publ. Geol. Espec. Ingeominas, 2: $1-186$.

Fritel, P.-H. (1906): Sur les variations morphologiques d'Acanthoceras Milletianum, d'Orb. sp. - Le Naturaliste, 28 (472): 245247.

Gentil, L. (1902): Esquisse stratigraphique et pétrographique du Bassin de la Tafna (Algérie): 275 p., Alger (Jourdan).

Heldt, M., Bachmann, M. \& Lehmann, J. (2008): Microfacies, biostratigraphy, and geochemistry of the hemipelagic BarremianAptian in north-central Tunisia: Influence of the OAE 1a on the southern Tethys margin. - Palaeogeogr., Palaeoclimatol., Palaeoecol., 261 (3/4): 246-260.

Heldt, M., Lehmann, J., Bachmann, M., Negra, M.E.H. \& Kuss, J. (2010): Increased terrigenous influx but no drowning: Palaeoenvironmental evolution of the Tunisian carbonate plat- 
form margin during the Late Aptian. - Sedimentology, 57: 695-719.

Hfaiedh, R., Arnaud Vanneau, A., Godet, A., Arnaud, H., Zghal, I., Ouali, J., Latil, J.-L. \& Jallali, H. (2013): Biostratigraphy, palaeoenvironments and sequence stratigraphy of the Aptian sedimentary succession at Jebel Bir Oum Ali (northern chain of Chotts, south Tunisia): Comparison with contemporaneous Tethyan series. - Cretaceous Res., 46: 177-207.

Janssen, N.M.M. (1997): Mediterranean Neocomian belemnites; part 1: Río Argos sequence (province of Murcia, Spain): The Berrias-Valanginian and the Hauterivian-Barremian boundaries. - Scripta Geol., 114: 1-55.

Janssen, N.M.M. \& Fözy, I. (2003): Neocomian belemnites from the Bersek Hill (Gerecse Mountains, Hungary). - Fölgtani Köslöny, 133 (2): 291-294.

Janssen, N.M.M., Clément, A. \& Bont, W. (2012): Mediterranean Neocomian belemnites, part 4: Belemnites of the Barremian stratotype section. - Carnets Géol. [Notebooks Geol.], Mem. 2012/02: 201-274.

Klein, J. \& Bogdanova, T.N. (2013): Lower Cretaceous ammonites VI. Douvilleiceratoidea and Deshayesitoidea. - In: Riegraf, W. (ed.): Fossilium Catalogus I: Animalia, 151: 299 p.; Leiden/NL (Backhuys).

Latil, J.-L. (2011): Early Albian ammonites from Central Tunisia and adjacent areas of Algeria. - Rev. Paléobiol., 30 (1): 321 429.

Lehmann, J., Heldt, M., Bachmann, M. \& Negra, M.E.H. (2009): Aptian (Lower Cretaceous) biostratigraphy and cephalopods from north central Tunisia. - Cretaceous Res., 30: 895-910.

Lehmann, J., Ifrim, C., Bulot, L.G. \& Frau, C. (2015): Paleobiogeography of Early Cretaceous ammonoids. - In: Klug, C., Korn, D., De Baets, K., Kruta, I. \& Mapes, R.H. (ed.): Ammonoid paleobiology: From macroevolution to paleogeography. - Topics in Geobiol., 44: 229-257; Dordrecht (Springer).

Lehmann, J., Mosavinia, A. \& Wilmsen, M. (2019): Parahoplitid ammonites and narrowing down the Aptian/Albian boundary interval in northern Iran. - Cretaceous Res., 94: 207-228.

Luber, T.L., Bulot, L.G., Redfern, J., Frau, C., Arantegui, A. \& Masrour, M. (2017): A revised ammonoid biostratigraphy for the Aptian of NW Africa: Essaouira-Agadir Basin, Morocco. Cretaceous Res., 79: 12-34.

Luber, T.L., Bulot, L.G., Redfern, J., Nahim, M., Jeremiah, J., Simmons, M., Bodin, S., Frau, C., Bidgood, M. \& Masrour, M. (2019): A revised chronostratigraphic framework for the Aptian of the Essaouira-Agadir Basin, a candidate type section for the NW African Atlantic Margin. - Cretaceous Res., 93: 292-317.

Macgillivray, W. (1840): A manual of geology: 239 p.; London (Scott, Webster \& Geary).

Mutterlose, J. \& Wiedenroth, K. (2008): Early Cretaceous (Valanginian - Hauterivian) belemnites from western Morocco: Stratigraphy and palaeoecology. - Cretaceous Res., 29 (5/6): 814-829.

Mutterlose, J., Schmid, F. \& Spaeth, C. (1983): Zur Paläobiogeographie von Belemniten der Unter-Kreide in NW-Europa. - Zitteliana, 10: 293-307.

Nerodenko, V.M. (1983): Early Cretaceous belemnites from the south of the USSR [in Russian]. - In: Starobogatov, Y.I. \& Nesis, K.N. (ed.): Systematics and ecology of cephalopods: 42 43; Leningrad (Zool. Inst.).

Núnez-Useche, F., Moreno-Bedmar, J.A., Company, M. \& Barragán, R. (2014): A negative carbon isotope excursion within the Dufrenoyia furcata Zone: Proposal for a new episode for chemostratigraphic correlation in the Aptian. - Carnets Géol. [Notebooks Geol.], 14 (6): 129-137.

Owen, H.G. (1996): "Uppermost Wealden facies and Lower Greensand Group (Lower Cretaceous) in Dorset, southern England: correlation and palaeoenvironment" by Ruffell \& Batten (1994) and "The Sandgate Formation of the M20 Motorway near Ashford, Kent and its correlation" by Ruffell \& Owen (1995): Reply. - Proc. Geol. Assoc., 107: 74-76.

Pavlow, A. (1891): Deuxième partie. Bélemnites de Speeton et leurs rapports avec les bélemnites des autres pays. - In: Pavlow, A. \& Lamplugh, G.W. (ed.): Argiles de Speeton et leurs équivalents. - Bull. Soc. Impér. Naturalistes Moscow, n. S. 5 (2/3): 214-276.

Peron, A. (1889-1890): Description des mollusques fossiles des terrains crétacés de la région sud des hauts-plateaux de la Tunisie, recueillis en 1885 et 1886 par M. Philippe Thomas. - Explor. Sci. Tunisie, Paléont., 1: 327 p.

Pervinquiere, L. (1903): Étude géologique de la Tunisie centrale. Dir. génér. Trav. publics, 1903: 359 p.; Paris (Rudeval).

Pervinquiere, L. (1907): Études de paléontologie Tunisienne ; I. Céphalopodes des terrains secondaires. Texte. - Dir. génér. Trav. publics, 1907: 438 p.; Paris (Rudeval).

Raisossadat, S.N. (2006): The ammonite family Parahoplitidae in the Sanganeh Formation of the Kopet Dagh Basin, north-eastern Iran. - Cretaceous Res., 27: 907-922.

Riedel, L. (1938): Amonitas del cretácico inferior de la Cordillera Oriental. - Estud. Geol. y Paleont. Cord. Orient. Colombia, 2: 7-78.

Riegraf, W. (1998): Suborder Pachybelemnopseina nov. - In: Riegraf, W., Janssen, N.M.M. \& Schmitt-Riegraf, C. (ed.): Fossilium catalogus, 1. Animalia, 135: 237-287.

Sharikadze, M.Z., Kakabadze, M.V. \& Hoedemaeker, P.H. (2004): Aptian and Early Albian Douvilleiceratidae, Acanthohoplitidae and Parahoplitidae of Colombia. - Scripta Geol., 128: 313-514.

Sinzow, I. (1908): Untersuchungen einiger Ammonitiden aus dem Unteren Gault Mangyschlaks und des Kaukasus. - Verh. Kaiserl. Russ. Miner. Ges., 45: 455-519.

Soua, M. (2016): Cretaceous oceanic anoxic events (OAEs) recorded in the northern margin of Africa as possible oil and gas shale potential in Tunisia: An overview. - Int. Geol. Rev., 58: 277-320.

Spaeth, C. (1971): Untersuchungen an Belemniten des Formenkreises um Neohibolites minimus (Miller, 1826) aus dem Mittelund Ober-Alb Nordwestdeutschlands. - Beih. Geol. Jb., 100: $3-127$.

Spaeth, C. (1989): Hibolites obtusirostris (Pavlow, 1892 [sic]) und sein Vorkommen mit anderen Belemniten der Unterkreide von Helgoland (Nordsee, NW-Deutschland). - Münster. Forsch. Geol. Paläont., 69: 73-85.

Spath, L.F. (1923): A monograph of the Ammonoidea of the Gault, part I. - Palaeontogr. Soc., 1 (1): 1-72.

Stevens, G.R. (1973): Cretaceous belemnites. - In: Hallam, A. (ed.): Atlas of palaeobiogeography: 385-401; Amsterdam (Elsevier).

Stolley, E. (1911): Studien an den Belemniten der unteren Kreide Norddeutschlands. - Jber. Niedersächs. Geol. Ver., 4: 174-189.

Swinnerton, H.H. (1937): A monograph of British Cretaceous belemnites; part II. - Palaeontogr. Soc., 1936: XVII-XXXII, 1730.

Swinnerton, H.H. (1952): A monograph of British Cretaceous belemnites; part IV. - Palaeontogr. Soc., 1952: 53-62.

Szives, O., Csontos, L., Bujtor, L. \& Főzy, I. (2007): Aptian-Campanian ammonites of Hungary. - Geol. Hungarica, Ser. Palae- 
ontol., Fasc. 57 : 187 p.; Budapest (Inst. Regni Hungariae Geol.).

Trabelsi, K. (2012): La Formation Kebar de Tunisie Centrale: Litho-, biostratigraphie (charophytes, ostracodes) et évènements sédimentaires et tectono-eustatiques associés. - Mém. Dipl. Doct. Geosci., Fac. Sci. Univ. Sfax: 299 p.; Sfax/Tunisia.

Weiß, W. (2012): Small planktonic foraminiferal assemblages from the Boreal Aptian Hoheneggelsen KB 9 core (Hannover, northern Germany) - Distribution, biostratigraphy and palaeoceanography. - N. Jb. Geol. Paläont. Abh., 266 (3): 283-317.
Zaghbib-Turki, D. (2003): Cretaceous coral-rudist formations in Tunisia - Paleogeography and paleoecology. - In: Gili, E., Negra, M.E.H. \& Skelton, P.W. (ed.): North African Cretaceous carbonate platform systems. - NATO Sci. Ser., 28: 83-110.

Manuscript received: 12.09 .2019

Revisions required: 25.11.2019

Revised version received: 16.01 .2020

Accepted for publication: 04.02.2020 